\title{
Apoptosis in hematopoietic cells (FL5.12) caused by interleukin-3 withdrawal: relationship to caspase activity and the loss of glutathione
}

\author{
Heidi K. Bojes ${ }^{1}$, Xiang Feng ${ }^{1}$, James P. Kehrer ${ }^{1,3}$ and \\ Gerald M. Cohen ${ }^{2}$ \\ 1 Division of Pharmacology and Toxicology, College of Pharmacy, The \\ University of Texas at Austin, Texas, USA \\ 2 MRC Toxicology Unit, Hodgkin Building, University of Leicester, P.0. 138, \\ Lancaster Road, Leicester, LE1 9HN, UK \\ ${ }^{3}$ corresponding author: James P. Kehrer, PhD, Division of Pharmacology and \\ Toxicology, College of Pharmacy, The University of Texas at Austin, Austin, \\ Texas 78712-1074, USA. tel: 512-471-1107; fax: 512-471-5002; \\ e-mail: kehrerjim@mail.utexas.edu
}

Received 15.5.98; revised 24.8.98; accepted 17.9.98 Edited by J.C. Reed

\begin{abstract}
The mechanism of cell death caused by cytokine deprivation remains largely unknown. FL5.12 cells (a murine prolymphocytic cell line), following interleukin-3 (IL-3) withdrawal, undergo a decrease in intracellular glutathione (GSH) that precedes the onset of apoptosis. In the present study, the induction of apoptosis following IL-3 withdrawal or GSH depletion with DL-buthionine-[S,R,]-sulfoximine (BSO) was examined. Both conditions caused time-dependent increases in phosphatidylserine externalization, acridine orange and ethidium bromide staining, decreases in mitochondrial membrane potential, processing and activation of caspase-3 and proteolysis of the endogenous caspase substrate poly(adenosine diphosphate ribose)polymerase (PARP). Apoptosis induced by IL-3 deprivation but not BSO also caused lamin $B_{1}$ cleavage, suggesting activation of caspase6. Despite a more profound depletion of GSH after BSO than withdrawal of IL-3, the extent of apoptosis was somewhat lower. Benzyloxycarbonyl-Val-Ala-Asp(OMe)fluoromethyl ketone (z-VAD.fmk) blocked this caspase activity and prevented cell death after BSO exposure but not after IL-3 deprivation. Following IL-3 withdrawal, the caspase inhibitors Z-VAD.fmk and boc-asp(OMe)fluoromethylketone (boc-asp.fmk) prevented the cleavage and activation of caspase-3, the breakdown of lamin $B_{1}$ and partially mitigated PARP degradation. However, the externalization of phosphatidylserine, the fall in mitochondrial membrane potential and subsequent apoptotic cell death still occurred. These results suggest that IL-3 withdrawal may mediate cell death by a mechanism independent of both caspase activation and the accompanying loss of GSH.
\end{abstract}

Keywords: apoptosis; caspases; glutathione; interleukin-3; FL5.12 cells
Abbreviations: IL-3, interleukin-3; GSH, glutathione; BSO, DLbuthionine-[S,R]-sulfoximine; DEVD.AMC, acetyl-Asp-Glu-ValAsp-amino methyl coumarin; PARP, poly(adenosine diphosphate ribose) polymerase; z-VAD.fmk, benzyloxycarbonyl-Val-Ala-Asp(OMe)-fluoromethyl ketone; boc-asp.fmk, boc-asp-(OMe)-fluoromethyl ketone; GSSG, glutathione disulfide; $\mathrm{DiOC}_{6}, 3,3$ '-dihexylacarbocyanine iodide

\section{Introduction}

Apoptosis is a structurally distinct form of cell death that involves a series of well-organized steps requiring active cellular participation. It is critical during development and tissue homeostasis as well as in the pathogenesis of a variety of diseases. ${ }^{1,2}$ Apoptosis occurs in two phases; an initial commitment to cell death phase followed by an execution phase characterized by distinct structural changes. ${ }^{3}$ These alterations include cell shrinkage, nuclear condensation, DNA fragmentation, externalization of phosphatidylserine and, finally, the breakdown of the cell into small fragments (apoptotic bodies) that in most tissues are then phagocytosed.

Increased attention has been focused on the role of a growing family of cysteine aspartate proteases (caspases) as mediators of the various changes associated with the execution phase of apoptosis. ${ }^{4,5}$ To date, at least ten different caspase-related proteases have been identified, ${ }^{6}$ all of which are synthesized as inactive precursors requiring cleavage at specific Asp residues to form the active enzyme., ${ }^{7,8}$ Although caspases are responsible for the cleavage of many important cellular substrates resulting in the stereotypic morphological changes associated with apoptosis the precise ordering of these caspases in all forms of apoptosis and whether all critical ones have been identified, is not known.

Multiple lines of evidence implicate caspase-3 (CPP32/ Apopain/YAMA) as a key executioner of apoptosis. For example, in many biological systems this enzyme cleaves intracellular proteins including poly(adenosine diphosphate ribose) polymerase (PARP, UI-70K and DNA-PKcs, ${ }^{9-11}$ and its inhibition prevents apoptosis. ${ }^{12}$ Further, caspase-3, the most closely related caspase to ced-3, is widely distributed and is highly expressed in cells of lymphocytic origin, suggesting that it may be an important mediator of apoptosis in the immune system. ${ }^{13}$ Other caspases, such as caspase-7 (Mch3/ICE-LAP3) which is closely related to caspase-3, and caspase-1, can also be critical in apoptosis as they may cleave the same substrates. ${ }^{6}$ However, because apoptosis proceeds normally in caspase-1(interleukin converting enzyme-ICE)-deficient mice, this caspase may not be essential, and it may not be a true mammalian ced-3 counterpart. ${ }^{14,15}$ 
Apoptosis can be initiated by a variety of stimuli including reactive oxygen species (ROS). ${ }^{16-18}$ Although disputed, several lines of evidence implicate such species as key mediators in apoptosis. For example, the formation of ROS can usually be detected upon the induction of apoptosis by a variety of means including xenobiotics, withdrawal of serum or other required growth factors and corticosteroids. Various antioxidants [including glutathione (GSH)] inhibit apoptosis induced by both oxidizing and nonoxidizing agents. ${ }^{19,20}$ Furthermore, depleting GSH with DLbuthionine-[S,R,]-sulfoximine [BSO] or diethyl maleate induced apoptosis ${ }^{21}$ and the diethyl maleate effect could be reversed by $\mathrm{N}$-acetylcysteine. This suggested that antioxidants may provide some protection by slowing oxidative processes that occur in the absence of GSH.

Although a depletion of intracellular GSH occurs in several different cell types, including FL5.12 cells, at very early stages of apoptosis, ${ }^{22-24}$ the intracellular oxidation usually assumed to occur following GSH loss has not always been substantiated. One explanation for this discrepancy is that the oxidative tonus of cells exposed to anti-fas antibody to induce apoptosis is increased by the stimulation of GSH efflux and not by the formation of oxidative species. ${ }^{24}$ Attempts to enhance GSH content in these cells did not prevent apoptosis, possibly due to rapid efflux. In contrast, the inhibition of $\mathrm{GSH}$ efflux by bcl-2 overexpression $^{22}$ or chemically ${ }^{25}$ is highly protective.

Taken together, these data suggest that several apoptotic pathways involve cellular thiols and thus modification of intracellular GSH content may be a key factor in apoptosis. In order to better understand the role of GSH in apoptosis FL5.12 cells were either deprived of IL-3 or depleted of GSH with BSO. Both treatments caused a time-dependent increase in apoptosis. Caspase inhibitors prevented apoptosis in BSO-treated cells suggesting a caspase-dependent mechanism, but did not block apoptotic changes or non-apoptotic decreases in viability following IL3 withdrawal. Therefore, cell death after IL-3 deprivation is mediated by more than the loss of GSH and may involve a caspase-independent mechanism.

\section{Results}

\section{Loss of intracellular GSH following IL-3 withdrawal and BSO exposure}

The loss of GSH following IL-3 withdrawal in FL5.12 cells has been shown previously ${ }^{22}$ and was confirmed in the present study. IL-3 deprivation caused a time-dependent decrease of intracellular GSH beginning within $3 \mathrm{~h}$. GSH levels were maximally $(\sim 60 \%)$ decreased by $24 \mathrm{~h}$ (Figure 1$)$. BSO treatment caused an overall greater reduction of GSH than IL-3 deprivation. Beginning at $3 \mathrm{~h}$ after BSO, GSH content was reduced by $70 \%$ and at $9 \mathrm{~h}$ GSH levels were depleted to values less than $10 \%$ of controls (Figure 1). GSH levels remained reduced for the $48 \mathrm{~h}$ period examined (data not shown). No changes in glutathione disulfide (GSSG) were detected in either cells deprived of IL-3 or treated with BSO (Table 1).

To investigate whether caspases were involved in the mechanism by which IL-3 deprivation and BSO administration caused GSH depletion, cells were incubated with $200 \mu \mathrm{M}$ z-VAD.fmk, a cell permeable irreversible inhibitor of caspase-1 and caspase-3 homologs. ${ }^{26-28}$ Although the presence of z-VAD.fmk appeared to slightly accelerate the loss of GSH following BSO, it had no effect after

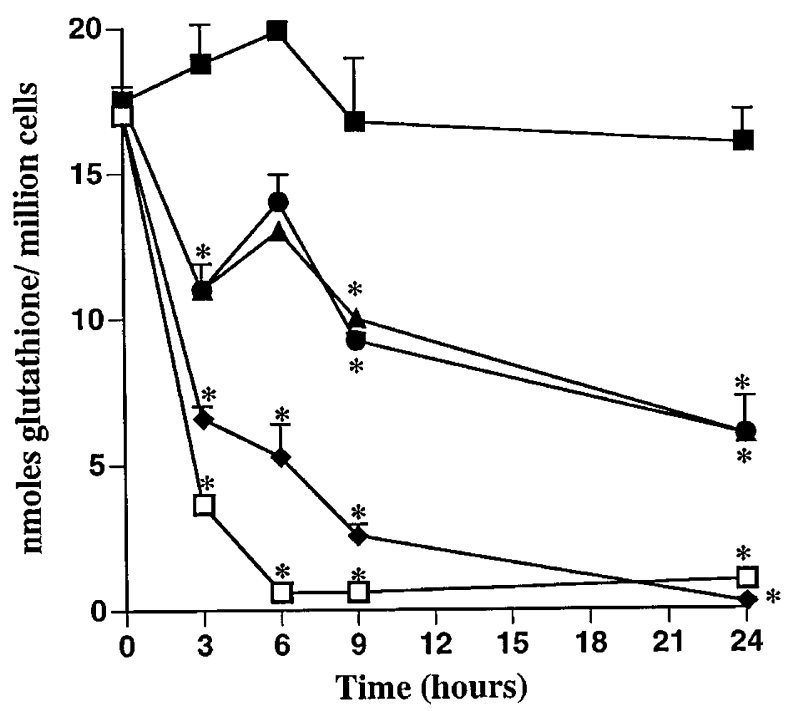

Figure 1 Loss of GSH following IL-3 withdrawal and after BSO exposure. Cells were left untreated, cultured in IL-3 free media or exposed to BSO $(10 \mathrm{mM})$. The effect of $z-V A D . f m k(200 \mu \mathrm{M})$ was examined on cells deprived of IL-3 and treated with BSO. At indicated time points, cells $\left(1 \times 10^{6} \mathrm{ml}^{-1}\right)$ were collected by centrifugation and GSH was derivatized with dansyl chloride prior to separation and detection with HPLC as described under Materials and Methods. Data points show mean \pm S.E. $(n=3-4)$. *Significantly different from time zero. ( $\boldsymbol{\square})+\mathrm{IL}-3 ;(\boldsymbol{\bullet})-\mathrm{IL}-3$; ( $\boldsymbol{\Delta}-\mathrm{IL}-3$ in the presence of Z-VAD.fmk; ( $)$ BSO; ( $\square$ ) BSO in the presence of Z-VAD.fmk

Table 1 Cells were left untreated, cultured in IL-3 free media or exposed to BSO $(10 \mathrm{mM})$.

\begin{tabular}{|c|c|c|c|c|c|}
\hline \multirow[b]{3}{*}{ Treatment } & \multicolumn{5}{|c|}{ GSSG (nmoles $/ 10^{6}$ cells) } \\
\hline & \multicolumn{5}{|c|}{ Time (hours) } \\
\hline & 0 & 3 & 6 & 9 & 24 \\
\hline $\begin{array}{l}+\mathrm{IL}-3 \\
-\mathrm{IL}-3 \\
\mathrm{BSO}\end{array}$ & $\begin{array}{l}0.32 \pm 0.02 \\
0.32 \pm 0.02 \\
0.32 \pm 0.02\end{array}$ & $\begin{array}{l}0.43 \pm 0.86 \\
0.40 \pm 0.10 \\
0.36 \pm 0.09\end{array}$ & $\begin{array}{l}0.37 \pm 0.05 \\
0.43 \pm 0.10 \\
0.29 \pm 0.13\end{array}$ & $\begin{array}{l}0.36 \pm 0.07 \\
0.42 \pm 0.12 \\
0.24 \pm 0.10\end{array}$ & $\begin{array}{l}0.37 \pm 0.16 \\
0.30 \pm 0.09 \\
0.23 \pm 0.10\end{array}$ \\
\hline
\end{tabular}

At indicated time points, cells were collected by centrifugation and GSSG was derivatized with dansyl chloride prior to separation and detection with HPLC as described under Materials and Methods. Data points show mean \pm S.E. $(n=3-4)$ 
withdrawing IL-3 indicating that GSH levels are not regulated by caspase-3-like proteases (Figure 1).

\section{z-VAD.fmk blocks apoptosis induced by BSO but not by IL-3 withdrawal}

A significant fourfold increase in apoptosis, as assessed by phosphatidylserine externalization on viable cells (as assessed by propidium iodide staining), was apparent at $9 \mathrm{~h}$ and was maximal at $20 \mathrm{~h}$ after IL-3 deprivation (tenfold increase over controls) (Figure 2A). These results were confirmed by examining cellular morphology using a combination of the fluorescent dyes acridine orange and ethidium bromide, which can differentiate apoptotic from necrotic cells. ${ }^{29}$ In the presence of IL-3, the percentages of apoptotic and necrotic cells were $\sim 5$ and $\sim 4$, respectively, up to $24 \mathrm{~h}$. Following IL-3 withdrawal, apoptosis increased to $17 \%$ of viable cells at $9 \mathrm{~h}$, and to $31 \%$ at $24 \mathrm{~h}$. Cell viability, as assessed by propidium iodide exclusion, remained at $\sim 80 \%$ up to $20 \mathrm{~h}$ after IL-3 was withdrawn, but decreased significantly to $55 \%$ at $24 \mathrm{~h}$ (data not shown). Thus, the onset of apoptosis occurred prior to any significant decreases in overall cell viability and correlated with the loss of GSH (Figure 1).

Cells were next treated with BSO to determine whether GSH depletion could cause apoptosis similar to that observed in cells deprived of a growth factor. BSO caused an $\sim$ twofold increase in the percentage of viable cells that were apoptotic by $6 \mathrm{~h}$ (Figure 2B). Cell viability after BSO, as measured by propidium iodide exclusion, was $\sim 86 \%$ (14\% of the cells were necrotic) up to $30 \mathrm{~h}$ when it was significantly reduced to $\sim 70 \%$ (data not shown). Thus, similar to deprivation of IL-3, BSO-induced apoptosis was evident before any significant change in overall cell viability occurred.

In contrast to cells deprived of IL-3 that exhibited a tenfold increase in apoptosis, BSO exposure only caused a fourfold induction of apoptosis at $24 \mathrm{~h}$ despite a greater reduction in GSH content. Because viability remained high and only a relatively small percentage of cells were apoptotic $24 \mathrm{~h}$ after BSO treatment, the time course was extended. Apoptosis did not significantly change up to $48 \mathrm{~h}$ after BSO when compared to values at $24 \mathrm{~h}$. However, it should be noted that since the number of propodium iodide including-cells increased after $30 \mathrm{~h}$ and the percentage of apoptotic cells was still maintained within a smaller population of viable cells, it is likely that some of these apoptotic cells were undergoing secondary necrosis. These results with phosphatidylserine externalization were confirmed using acridine orange and ethidium bromide staining. Apoptosis by this method increased from basal levels of 6 to $22 \%$ and $15 \%$ at 24 and $48 \mathrm{~h}$ after BSO, respectively. Collectively, these results suggest that reducing GSH may not be the critical factor responsible for the increase in apoptosis observed after IL-3 withdrawal.

To investigate the role of caspases in the apoptosis caused by IL-3 withdrawal and BSO treatment, cells were incubated with z-VAD.fmk. Although this caspase inhibitor completely abrogated the increase in apoptotic cells by
BSO, it did not affect the increasing number of non-viable cells and only delayed by $3 \mathrm{~h}$ the apoptosis induced by IL-3 withdrawal (Figure $2 \mathrm{~A}$ and $\mathrm{B}$ ). Administration of a second dose of z-VAD.fmk at $9 \mathrm{~h}$ did not prevent the

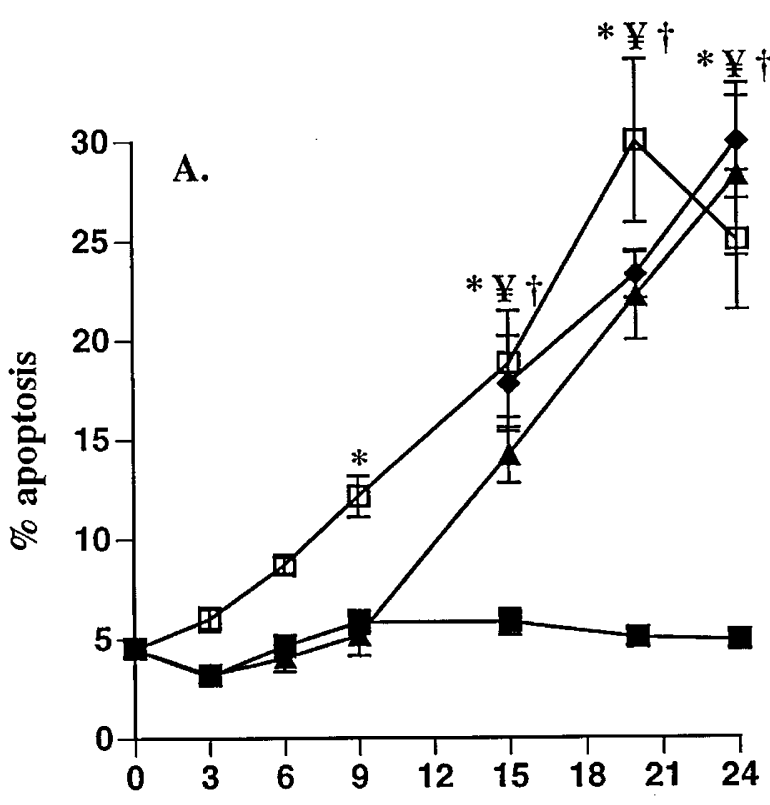

Time (hours)

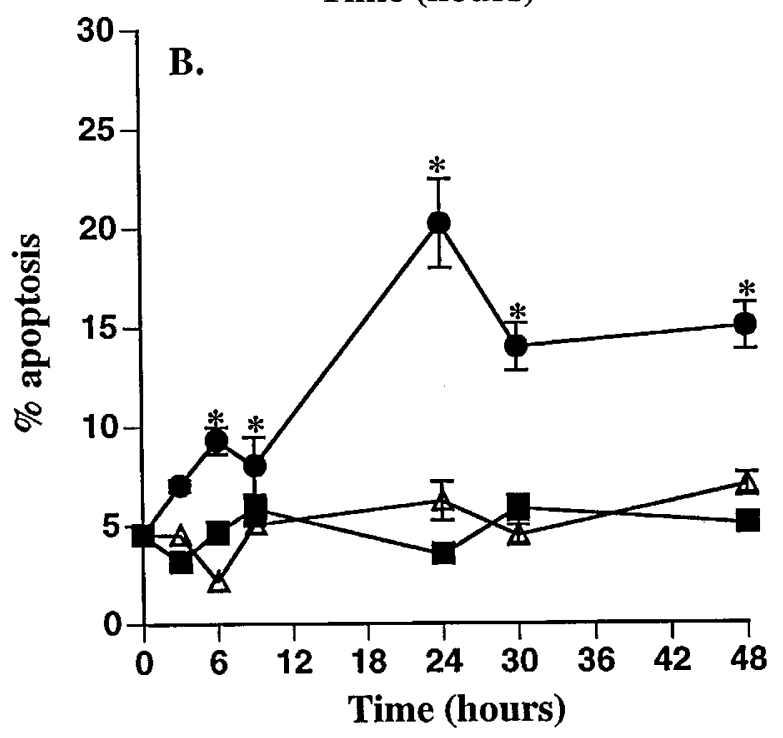

Figure 2 Caspase inhibitors block apoptosis induced by BSO but not following II-3 withdrawal. The percentage of apoptotic cells was determined by flow cytometric analysis following FITC labelling of Annexin V binding and exclusion of propidium iodide, respectively, as described under Materials and Methods. Data points show mean \pm S.E. $(n=3-9){ }^{*}, ¥, \uparrow$ Significantly different from time zero for cells deprived of IL-3, deprived of IL-3 and incubated with either z-VAD.fmk or boc-asp.fmk, respectively. (A) Cells were left untreated or cultured in IL-3 free media. The effect of z-VAD.fmk $(200 \mu \mathrm{M})$ or boc.asp.fmk $(200 \mu \mathrm{M})$ was examined on cells deprived of IL-3. (B) Cells $\left(1 \times 10^{6} \mathrm{ml}^{-1}\right)$ were cultured in media supplemented with IL-3. The effect of BSO $(10 \mathrm{mM})$ was examined on cells in the presence or absence of z-VAD.fmk $(200 \mu \mathrm{M})$. ( $\mathbf{D})+\mathrm{IL}-$ 3; $(\square)-$ IL-3; $(\mathbf{\Delta})-$ IL-3 in the presence of Z-VAD.fmk; $(-$ IL-3 in the presence of boc-asp.fmk; $(\bullet) B S O ; \triangle)$ BSO in the presence of z-VAD.fmk 
subsequent increase in apoptosis (data not shown) indicating that the failure to prevent apoptosis was not due to a limited supply of inhibitor.

The effect of boc-asp.fmk, a broad spectrum caspase inhibitor, ${ }^{30}$ on cells deprived of IL-3 was examined at 15, 20 and $24 \mathrm{~h}$, time points that displayed large increases in apoptosis. Similar to z-VAD.fmk, boc-asp.fmk was unable to mitigate the increase in apoptosis induced by withdrawal of IL-3 (Figure 2A). Results obtained using acridine orange and ethidium bromide were similar (data not shown). These results suggest that the apoptosis that occurs upon withdrawal of IL-3 does not require caspase activity.

\section{Caspase inhibitors do not prevent the fall in mitochondrial membrane potential following IL-3 withdrawal and BSO treatment}

In several models of apoptosis, a decrease in mitochondrial membrane potential precedes nuclear apoptotic changes. $^{31-33}$ The number of cells with decreased mitochondrial membrane potential became significant $15 \mathrm{~h}$ after withdrawal of IL-3 and included $\sim 20 \%$ of all cells within $24 \mathrm{~h}$ (Figure 3A). Neither z-VAD.fmk nor boc-asp.fmk could prevent this decrease, suggesting that either changes in mitochondrial membrane potential following withdrawal of IL-3 lie upstream of caspase activation or that caspases are not involved in this process. Interestingly, at $24 \mathrm{~h}$ the presence of caspase inhibitors seemed to increase the number of IL-3 deprived cells with reduced mitochondrial membrane potential. The significance of this effect is not known.

In contrast to withdrawing IL-3, mitochondrial membrane potential was maintained with BSO exposure until $48 \mathrm{~h}$ when $\sim 14 \%$ of cells demonstrated a decline (Figure 3B). Interestingly, the onset of apoptosis occurred prior to the drop in mitochondrial membrane potential, suggesting this change is not essential for apoptosis.

\section{Processing of caspase- 3 accompanies the induction of apoptosis caused by IL-3 withdrawal and BSO treatment}

Western blot analyses were performed using antibodies to the 117 fragment of caspase-3 to determine whether timedependent processing of caspase-3 occurred following IL-3 withdrawal and after BSO exposure. In untreated cells, immunoblots showed the presence of the $32-\mathrm{kD}$ precursor of caspase-3 (Figure 4A). After withdrawal of IL-3, the p17 subunit of the mature caspase- 3 enzyme was detected at $9 \mathrm{~h}$ and increased relative to the 32-kD precursor to $24 \mathrm{~h}$ (Figure 4B). Concurrently, a time-dependent decrease in the level of the $32-\mathrm{kD}$ precursor of caspase-3 occurred. After BSO exposure a time-dependent increase in the 17$\mathrm{kD}$ fragment was evident at $9 \mathrm{~h}$, although no decreases in the 32-kD precursor were noted (Figure $4 \mathrm{C}$ ). The caspase inhibitor z-VAD.fmk completely blocked the loss of the procaspase- 3 and the formation of the $\mathrm{p} 17$ subunit following both IL-3 deprivation and BSO exposure (Figure 4A and B).

\section{PARP and lamin $B_{1}$ degradation following IL-3 withdrawal and BSO treatment}

The intact form of PARP (116-kD) (Figure 4D) and lamin $\mathrm{B}_{1}(66-\mathrm{kD})$ (Figure $\left.4 \mathrm{E}\right)$ was detected in the presence of IL-3. After IL-3 withdrawal, 116-kD PARP and 66-kD lamin $\mathrm{B}_{1}$ decreased with time and within $24 \mathrm{~h}$ the proforms were dramatically reduced (Figure 4D and E). Coincident to
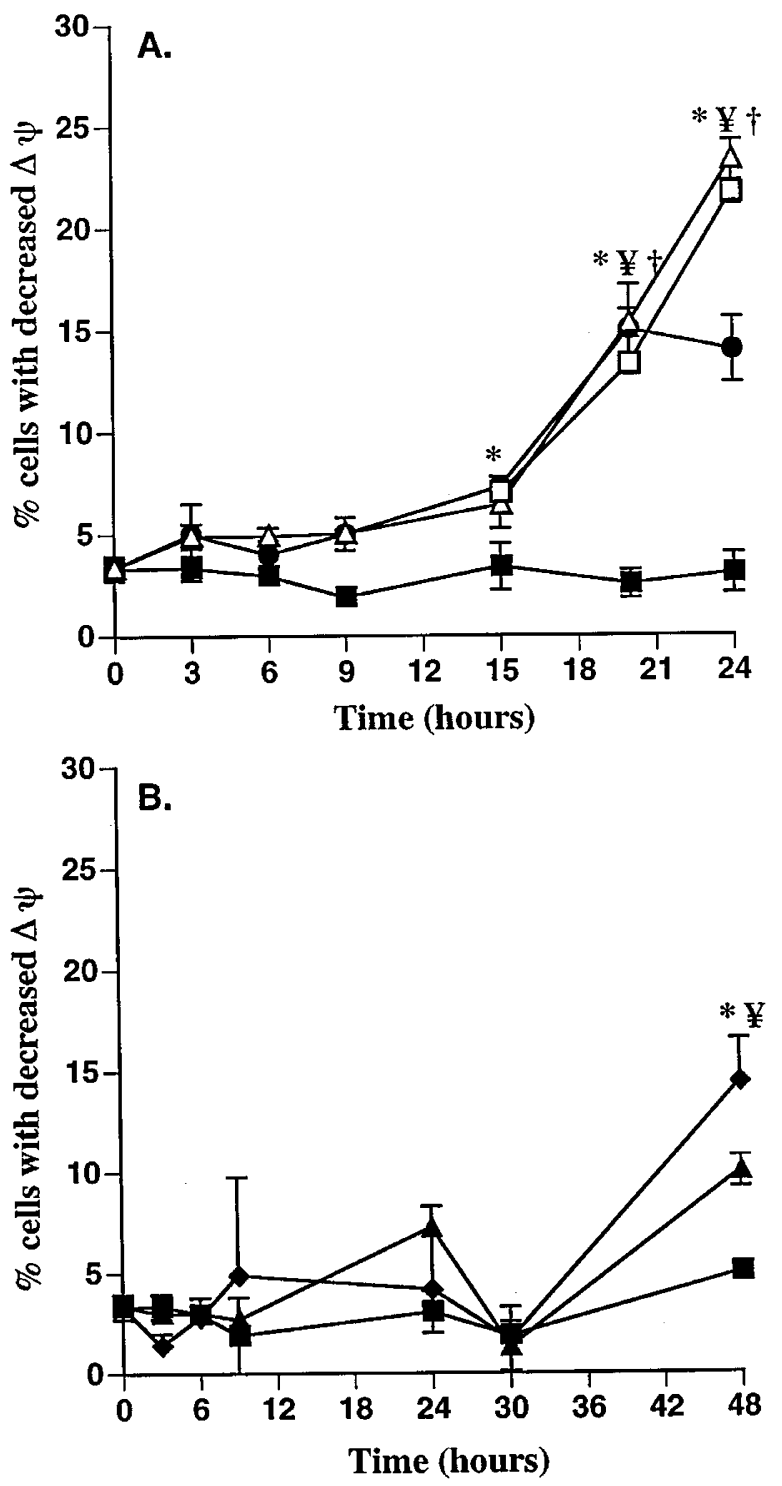

Figure 3 IL-3 deprivation and BSO exposure decreases the mitochondrial membrane potential. The percentage of cells with decreased mitochondrial membrane potential was determined by flow cytometric analysis as described under Materials and Methods. Data points show mean + S.E. $(n=3-9)$.

${ }^{*}, ¥, \uparrow$ Significantly different from time zero for cells deprived of IL-3, deprived of IL-3 and incubated with either z-VAD.fmk or boc-asp.fmk, respectively. (A) Cells were left untreated or cultured in IL-3 free media. The effect of $z$ VAD.fmk $(200 \mu \mathrm{M})$ or boc.asp.fmk $(200 \mu \mathrm{M})$ was examined on cells deprived of IL-3. (B) Cells were cultured in media supplemented with IL-3. The effect of BSO $(10 \mathrm{mM})$ was examined on cells in the presence or absence of $z$ -

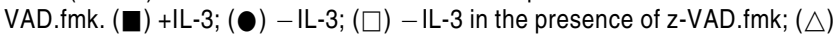
- IL-3 in the presence of boc-asp.fmk; $(\bullet) B S O ;(\boldsymbol{\Lambda})$ BSO in the presence of z-VAD.fmk 
the disappearance of the proforms was the appearance of the $85-\mathrm{kD}$ and $43-\mathrm{kD}$ fragments of PARP and lamin $\mathrm{B}_{1}$, respectively. Therefore, several target proteins are cleaved in the execution phase of apoptosis following IL-3 withdrawal. Cleavage of PARP suggests activation of caspase-3 and $-7^{12,34}$ and breakdown of lamin $B_{1}$ suggests activation of caspase- 6 . $^{35,36}$

Although z-VAD.fmk, an inhibitor with greater specificity for caspase-3 than boc-asp.fmk, abrogated the formation of the $85-\mathrm{kD}$ and $43-\mathrm{kD}$ fragments of PARP and lamin $\mathrm{B}_{1}$, respectively, it did not completely protect against the degradation of the 116-kD PARP that occurred after withdrawal of IL-3 (Figure 4D and E). In contrast, the broad spectrum caspase inhibitor boc-asp.fmk was unable to prevent the breakdown of PARP or lamin $B_{1}$ at $24 \mathrm{~h}$ (Figure $4 \mathrm{D}$ and $\mathrm{E}$ ). Taken together these results suggest that IL-3 withdrawal activates a caspase and/or protease that targets PARP and is at least partially resistant to the caspase inhibitors tested.
In cells exposed to BSO for $24 \mathrm{~h}$, a large decrease in 116-kD PARP and a small increase in the $85-\mathrm{kD}$ fragment occur similar to the changes seen after withdrawal of IL-3 (Figure 4F). The degradation of PARP following BSO treatment was prevented by either z-VAD-fmk or bocasp.fmk. However, unlike cells deprived of IL-3, cells exposed to BSO did not demonstrate any breakdown of lamin $B_{1}$ (Figure 4G). Because $z-V A D . f m k$ prevented apoptosis after BSO, together these results suggest that the apoptosis caused by BSO is mediated by caspases.

\section{IL-3 withdrawal and BSO exposure activate DEVD.amc cleavage in cell lysates}

The activation of a caspase activity is considered an important effector of apoptosis. In order to examine whether growth factor withdrawal and BSO treatment induced either casapase-3 or -1-like activities, the cleavage of the fluorogenic peptide substrates YVAD.amc

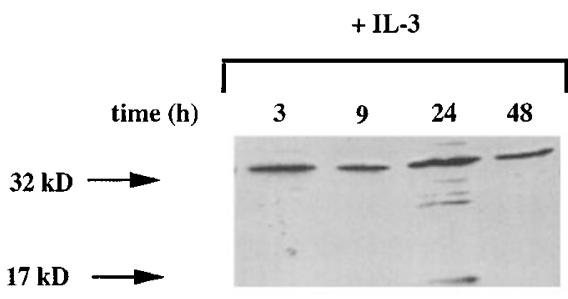

A.

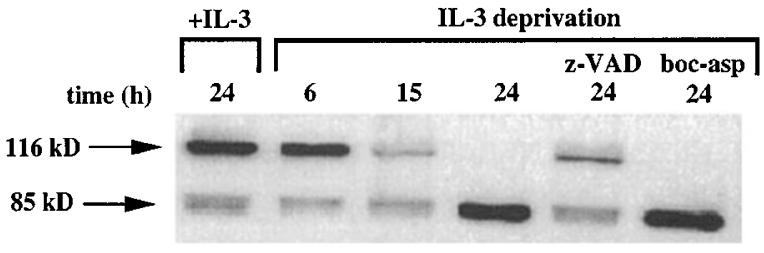

D.

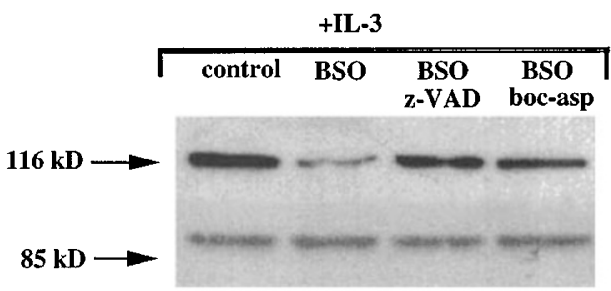

F.
IL-3 deprivation

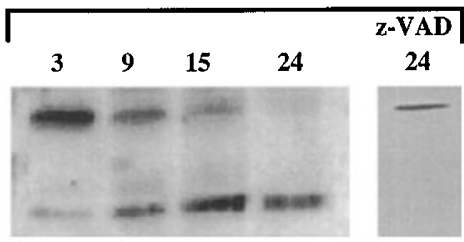

B.

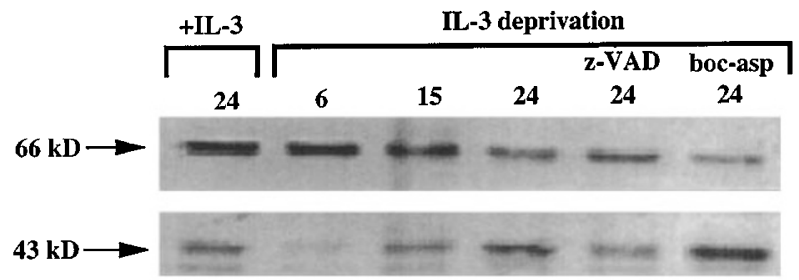

E.

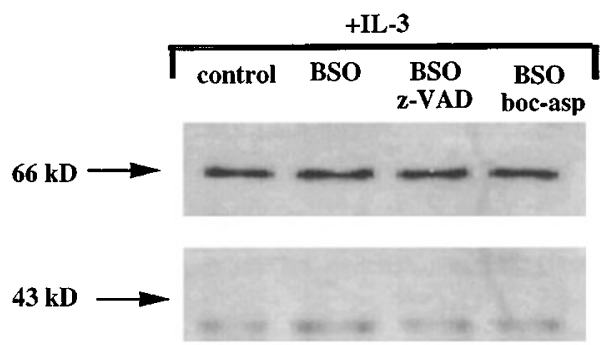

G.

Figure 4 Cleavage of caspase-3, PARP and lamin $B_{1}$ following IL-3 withdrawal and BSO treatment. Caspase 3 cleavage was assessed in untreated cells (A), cells cultured in IL-3 free media (B) or cells exposed to BSO $(10 \mathrm{mM})$ in the presence of IL-3 (C). The effect of Z-VAD.fmk $(200 \mu \mathrm{M})$ was examined on cells deprived of IL-3 and treated with BSO. At indicated time points, cells were collected and protein were resolved on a SDS-15\% polyacrylamide gel. Cells were analyzed using antibodies to caspase-3 as described under Materials and Methods. The proform of caspase-3 (32-kD) and cleaved proteolytic fragment (17-kD) are indicated by the upper and lower arrows, respectively. PARP $(\mathbf{D}, \mathbf{F})$ and lamin $B_{1}(\mathbf{E}, \mathbf{G})$ degradation were assessed in untreated cells or cells cultured in IL-3 free media or treated with BSO $(10 \mathrm{mM})$ for $24 \mathrm{~h}$. The effect of Z-VAD.fmk $(200 \mu \mathrm{M})$ or boc-asp.fmk $(200 \mu \mathrm{M})$ was examined at $24 \mathrm{~h}$. At the indicated times, cells were collected and proteins were resolved on a SDS-8\% polyacrylamide gel. Cells were analyzed using antibodies to PARP and lamin $\mathrm{B}_{1}$ as described under Materials and Methods. The proform of PARP $(116-\mathrm{kD})$ and cleaved proteolytic fragment $(85-\mathrm{kD})$, and the proform of lamin $\mathrm{B}_{1}(66-\mathrm{kD})$ and cleaved fragment $(43-\mathrm{kD})$ are indicated by the upper and lower arrows, respectively 
and DEVD.amc was measured. The DEVD.amc cleaving activity of lysates obtained from control cells was very low and did not increase during the time course studied (Figure $5 \mathrm{~A}$ and $\mathrm{B})$. In contrast, enzymatic cleavage of DEVD.amc was detected $9 \mathrm{~h}$ after IL-3 withdrawal and $30 \mathrm{~h}$ after BSO exposure and increased thereafter (Figure 5A and $B$ ). The addition of Ac.DEVD.cho, a caspase inhibitor relatively specific for caspases-3 and -7, or Z-VAD.fmk completely blocked caspase-3-like activity in cells deprived of IL-3 or treated with BSO. In contrast, no cleavage of YVAD.amc was detected using either apoptotic stimuli (data not shown). Taken together, these results suggest that caspase-3-like but not caspase-1-like proteases are activated in apoptosis mediated by $\mathrm{IL}-3$ withdrawal and BSO.

\section{Discussion}

\section{Apoptosis in IL-3 dependent cells}

Many hematopoietic cells are dependent on cytokines for growth and survival. Although the mechanism by which cytokine withdrawal causes apoptosis is thought to involve inactivation of signaling pathways, a role for ROS, GSH and caspases in this process has also been suggested. ${ }^{37,38}$ Caspases have attracted particular attention because of their similarity to the ced-3 'death' gene, and the ability of various inhibitors of these enzymes to block apoptosis induced by a variety of treatments.

\section{Caspase-independent apoptosis?}

Although the activation of several caspases clearly accompanied IL-3 withdrawal-induced apoptosis, neither caspase inhibitor tested could prevent apoptosis or the decrease in mitochrondrial membrane potential. The failure of an inhibitor with a broad spectrum of activity, such as boc-asp.fmk, to have an effect on apoptosis argues against a role for caspases. It remains possible, however, that caspase-3 may participate in the apoptotic process along with other caspases that are not effectively inhibited with zVAD.fmk. The inability of either caspase inhibitor used to completely block the breakdown of PARP and lamin $B_{1}$ suggests the presence of significant residual caspase activity that may mediate apoptosis in this system. Alternately, it is possible that other proteases are the agents that mediate the execution stage of apoptosis after IL-3 withdrawal.

Several recent studies using alternate approaches have demonstrated the potential for caspase-independent apoptosis. $^{39-41}$ For example, bax induced cell death in JURKAT cells was not prevented by various inhibitors of proteases. $^{39}$ Also demonstrated was a fall in mitochondrial membrane potential and an increase in ROS, implicating a role for mitochondria, possibly due to the opening of mitochondrial pores which release soluble pro-apoptotic factors such as cytochrome $c .^{42}$

Recently, it was shown that bcl-2 overexpression but not z-VAD.fmk prevented decreases in mitochondrial membrane potential and changes in plasma membrane integrity. This suggested that the activation of apoptogenic proteases occurs after changes in mitochondrial permeability. ${ }^{43-45}$ Consistent with these observations, a fall in mitochondrial membrane potential that was not blocked by caspase inhibitors was noted in the present study as an early event after IL-3 withdrawal. In contrast, cells treated with BSO only demonstrated significant changes in mitochondrial membrane potential at $48 \mathrm{~h}$; well after the onset of apoptosis. These results suggest that apoptosis caused by BSO occurs independently of
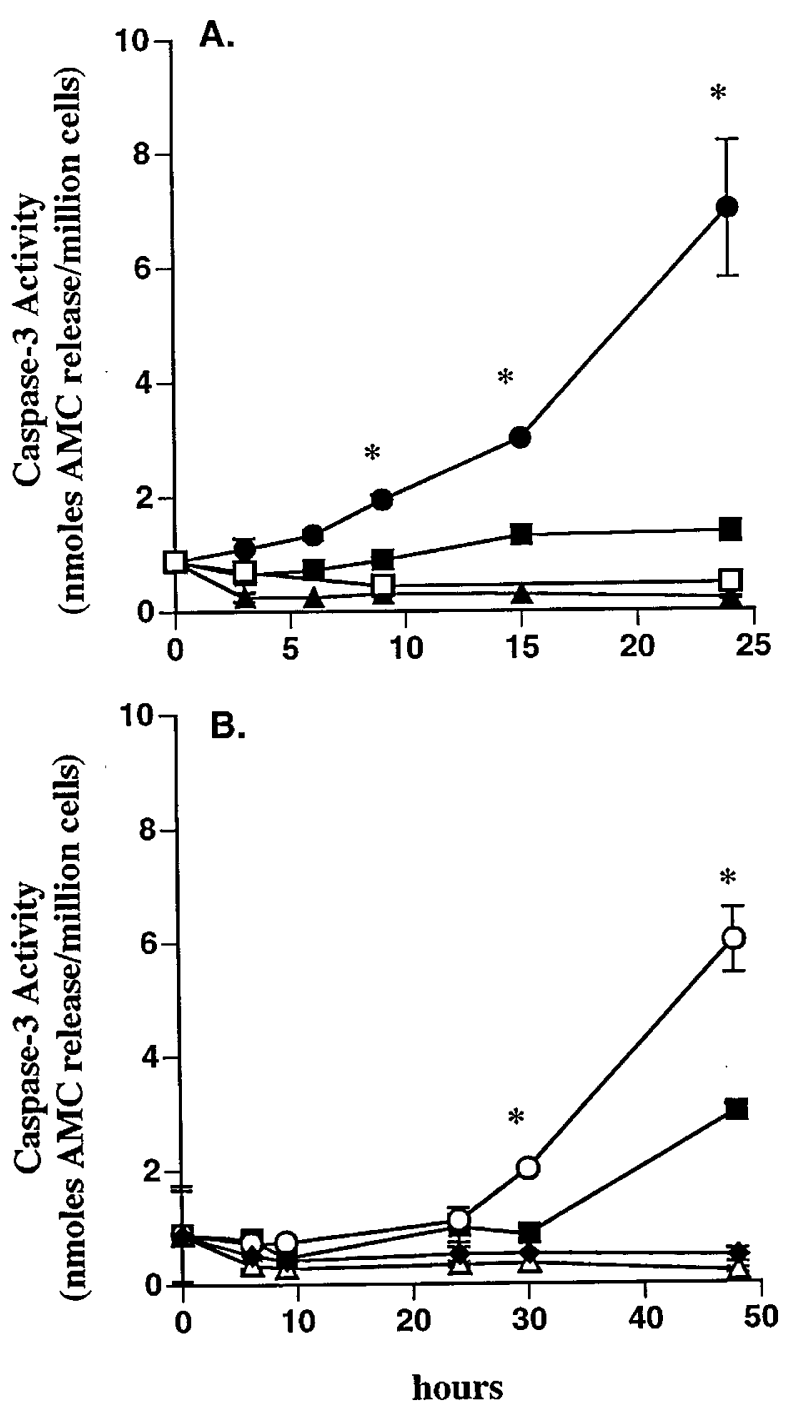

Figure 5 Cytosolic caspase-3 activity increases after IL-3 withdrawal and BSO treatment. Caspase-3-like activity was measured fluorometrically by its ability to release amc from the fluorogenic substrate Ac-DEVD.amc. Some cells were preincubated with caspase-3 inhibitor Ac-DEVD.cho $(50 \mu \mathrm{M})$ or zVAD.fmk $(200 \mu \mathrm{M})$. Data represent + S.E. $(n=3)$. *Significantly different from time zero. (A) Cells were left untreated or cultured in IL-3 free media. (B) Cells were cultured in media supplemented with IL-3. ( $(\mathbf{D})+\mathrm{IL}-3 ;(\mathbf{O})-\mathrm{IL}-3 ;(\mathbf{A})$ - IL-3 in the presence of AC-DEVD.cho; $(\square)-$ IL-3 in the presence of ZVAD.fmk; (O) BSO; $(\triangle)$ BSO in the presence of z-VAD.fmk; $(\bullet)$ BSO in the presence of Ac-DEVD.cho 
the changes in mitochondrial membrane potential but does not necessarily exclude a role for the mitochondria in this cell death system.

Cells treated with BSO to achieve levels of GSH comparable to those attained after cytokine deprivation appeared to undergo apoptosis in a caspase-dependent manner. This suggests that caspase activation may vary with different stimuli within similar as well as different cellular lineages. For example, apoptosis induced by IL-2 removal in T cells is mediated independently of caspases1 or -3 , although an unknown caspase member may be involved. $^{38,46}$ Others have shown that caspases such as caspase-8 (FLICE) are recruited to death receptor complexes such as CD95 (Fas/Apo 1) and play a proximal role in apoptosis. ${ }^{47,48}$ In general, while caspases are activated in most if not all apoptotic systems, and may mediate critical steps, their absolute requirement is unclear. It is possible that caspases are responsible for the proteolysis of many cellular substrates, which results in the stereotypic morphological and biochemical changes associated with apoptosis. Inhibition of the caspases may result in inhibition of these sterotypic changes but the cell is already committed to die. Thus, cell death still ensues but without the normal changes associated with apoptosis.

\section{Mechanism of apoptosis after GSH depletion}

Although the present study confirms that GSH depletion can induce apoptosis, ${ }^{21,23}$ the data suggest that this may not play a critical, or at least direct, role in apoptosis caused by cytokine deprivation. One factor that may account for the discrepancy between cytokine deprivation and BSO-induced apoptosis is that BSO only depletes cytosolic GSH, thereby preserving GSH levels in the mitochondria as well as the nucleus that may be the critical pools to prevent apoptosis. Recently, it was shown that bcl-2 overexpression causes redistribution of glutathione to the nucleus where it alters nuclear redox status and blocks caspase activity. ${ }^{49}$ This concept would explain the higher levels of $\mathrm{GSH}$ seen in cells that overexpress antiapoptotic bcl proteins. ${ }^{22,50,51}$

Despite the above evidence, the relationship between GSH and apoptosis remains unclear. BSO does not increase the susceptibility to radiation-induced apoptosis, ${ }^{51}$ suggesting that GSH does not directly regulate this process. It is possible that other cellular thiols such as thioredoxin may play a role. ${ }^{52}$ Others have shown an increase in apoptosis following diethyl maleate and diamide treatment. The effect of diamide, which causes a more general oxidation of cellular thiols subsequent to oxidation of $\mathrm{GSH}$, suggests that a shift in the redox state is important for apoptosis. Although GSSG was unchanged in the current study, the drop in GSH did change the redox balance; an effect that could promote apoptosis.

Because caspases contain critical thiol sites, modification of these residues by $\mathrm{GSH}$ may occur and regulate caspase activity. For example, $\mathrm{H}_{2} \mathrm{O}_{2}$ can delay apoptosis as well as prevent fas-induced apoptosis by directly inhibiting the cysteine residues on caspases. ${ }^{53}$ It is possible that GSH would keep caspases functional and primed by maintaining them in a reduced state. In support of this concept, Nicholson et al. ${ }^{12}$ showed that reducing agents maintained the activity of recombinant caspase-3. These results may also explain some of the discrepancies that are observed with GSH and apoptosis and also points out that regulation of apoptosis may be a subtle balance between the level of ROS and GSH and/or overall reducing equivalents in the cell.

In summary, these data show that both deprivation of IL-3 and treatment with BSO causes a loss of GSH, activates caspases and induces apoptosis in FL5.12 cells. The addition of caspase inhibitors prevented apoptosis in BSO-treated cells but had only minimal effects following IL-3 withdrawal. These results suggest that cell death after IL-3 deprivation occurs by a caspase-independent mechanism as well as independently of the loss of GSH.

\section{Materials and Methods}

\section{Materials}

RPMI-1640 media was purchased from Gibco (Paisley, UK). Benzyloxycarbonyl-Val-Ala-Asp(OMe)fluoromethyl ketone (zVAD.fmk) and boc-asp(OMe)fluoromethyl ketone (boc.asp.fmk) were obtained from Enzyme Systems, Inc (Dublin, CA, USA). The tetrapeptide caspase inhibitors, Acetyl-Asp-Glu-Val-Asp-aldehyde (Ac-DEVD.cho) and acetyl-Tyr-Val-Ala-Asp-aldehyde (Ac-YVAD.cho) were purchased from Calbiochem-Novabiochem Corp (LaJolla, CA, USA). The tetrapeptide caspase substrates, Acetyl-Asp-Glu-Val-Asp7-amino-4-methyl coumarin (Ac-DEVD.amc) and acetyl-Tyr-Val-AlaAsp-7-amino-4-methyl coumarin (Ac-YVAD.amc), were acquired from Research Biochemicals Internationals (Natick, MA, USA). Annexin VFITC kit was purchased from Bender MedSystems (Vienna, Austria). All other chemicals were from Sigma Chemical Co. (Poole, UK or St. Louis, MO, USA).

\section{Cell culture}

FL5.12 cells (an IL-3 dependent murine prolymphocytic cell line) were maintained in RPMI-1640 medium supplemented with $10 \%$ $(\mathrm{v} / \mathrm{v})$ heat-inactivated fetal calf serum, 10\% (v/v) WEHI-3Bconditioned medium, and $1 \%$ glutamine in a $5 \% \quad \mathrm{CO}_{2}: 95 \%$ air atmosphere at $37^{\circ} \mathrm{C}$. WEHI-3 cells were grown as described previously. ${ }^{54}$ Cultures were maintained in logarithmic growth phase by routine passage every $2-3$ days. The peptide caspase inhibitors were prepared as stock solutions in DMSO, and aliquots were added to the cultures keeping the DMSO at $\leqslant 0.1 \%$ (final concentration).

\section{Analysis of apoptosis and cell viability}

Apoptosis was assessed by measuring the binding of FITC labeled Annexin $\mathrm{V}$ protein to the phospholipid phosphatidylserine which is present on the external surface of the membrane of apoptotic cells. ${ }^{55,56}$ Cells $\left(1 \times 10^{6} \mathrm{ml}^{-1}\right)$ were incubated with FITC labeled Annexin $\mathrm{V}$ following the manufacturer's instruction. Non viable cells were assessed simultaneously by addition of propidium iodide. 
Analyses were conducted using a Becton Dickinson FACScan flow cytometer. After excluding non-viable cells (indicated by propodium iodide uptake and DNA binding), the remaining viable cells were displayed as a cytogram of appropriate fluorescence versus forward light scatter. Two populations of viable cells were obtained; normal and apoptotic cells with low and high FITCstaining, respectively.

Apoptosis was also assessed by fluorescence microscopy by mixing $2 \mu \mathrm{l}$ of acridine orange $(100 \mu \mathrm{g} / \mathrm{ml}), 2 \mathrm{ml}$ ethidium bromide $(100 \mu \mathrm{g} / \mathrm{ml})$ and $20 \mu \mathrm{l}$ of the cell suspension. A minimum of 200 cells were differentiated from 'dead' apoptotic, necrotic and normal cells by examining the changes in cellular morphology based on distinctive nuclear and cytoplasmic fluorescence. ${ }^{29}$

\section{Western blot analysis}

Cells $\left(2.5 \times 10^{6} \mathrm{ml}^{-1}\right)$ were collected by centrifugation at $400 \times g$ for $5 \mathrm{~min}$ and washed twice with cold phosphate-buffered saline, pH 7.4 (PBS). Proteins were resolved on either 8\% (PARP and lamin $B_{1}$ ) or $15 \%$ (caspase- 3 ) SDS polyacrylamide gels and blotted onto nitrocellulose (Hybond-C extra: Amersham, Little Chalfont, UK). Intact PARP (116-kD) and its apoptotic signature fragment (85-kD) were detected with a monoclonal antibody (a gift from Dr. G. Poirier, Laval University, Quebec, Canada). A mouse monoclonal antibody was used to detect both the intact form (66-kD) and cleaved product (43-kD) of lamin $B_{1}$ (Serotec, Oxford, UK). A goat polyclonal antibody was used to detect both the procaspase-3 (32-kD) and the p17 subunit (Santa Cruz, CA, USA). Detection was achieved using the appropriate secondary antibody (goat anti-mouse IgG or rabbit anti-goat $\lg G$ ) conjugated horseradish peroxidase and by enhanced chemiluminescence (Amersham, Little Chalfont, UK).

\section{Glutathione determination}

Glutathione was quantitated using a method previously described. ${ }^{57}$ Cells $\left(1 \times 10^{6} \mathrm{ml}^{-1}\right)$ were washed twice and precipiated with $200 \mu \mathrm{L}$ of $5 \%$ perchloric acid $(\mathrm{v} / \mathrm{v}), 2 \mathrm{mM}$ diethylenetriamincepentaacetic acid (DEPA), and $0.2 \mathrm{mM}$ boric acid. Protein was removed by centrifugation. After having alkylated free thiols with iodoacetic acid, the primary amines in the supernatant were derivatized with dansyl chloride. The derivatives of GSH and GSSG were then separated by HPLC and assessed fluorimetrically.

\section{Quantitation of mitochondrial transmembrane potential}

Cells $\left(1 \times 10^{6} \mathrm{ml}^{-1}\right)$ were incubated for $20 \mathrm{~min}$ at $37^{\circ} \mathrm{C}$ with $3,3^{\prime}$ dihexylacarbocyanine iodide $\left(\mathrm{DiOC}_{6} ; 50 \mathrm{nM}\right.$, Molecular Probes Inc. Eugene, OR, USA), which is retained in mitochondria with normal membrane potential. ${ }^{32}$ Cells were then incubated for 2 min with propidium iodide $(50 \mu \mathrm{g} / \mathrm{ml})$ followed by analysis on a Becton Dickinson FACScan flow cytometer. Forward and side scatters were gated on the major population of normal-sized cells. Non-viable cells (propidium iodide positive) were then excluded and the remaining viable cells were displayed as a cytogram of appropriate fluorescence versus forward light scatter. Two populations of viable cells were obtained, cells with high and low staining for $\mathrm{DiOC}_{6}$. In control experiments cells were incubated with carbonylcyanide $m$-chlorophenylhydrozone $\left(50 \mu \mathrm{M} ; 10 \mathrm{~min} ; 37^{\circ} \mathrm{C}\right)$, an uncoupling agent that abolishes the mitochondrial membrane potential.

\section{Measurement of caspases-3 and -1-like activities}

Caspases-3 and -1-like activities were determined following standard procedures. ${ }^{7,12,58}$ Specifically, cells $\left(0.7 \times 10^{6} \mathrm{ml}^{-1}\right)$ were collected and resuspended in $300 \mu \mathrm{l}$ of $0.5 \%$ Nonidet P-40, $0.5 \mathrm{mM}$ EDTA, $150 \mathrm{mM} \mathrm{NaCl}$ and $50 \mathrm{mM}$ Tris, $\mathrm{pH} \mathrm{7,5}$. Aliquots $(50 \mu \mathrm{l})$ of the extracts were incubated with $40 \mu \mathrm{M}$ tetrapeptide substrate (AcDEVD.amc or Ac-YVAD.amc), $10 \mathrm{mM}$ HEPES (pH 7.5), $0.05 \mathrm{M} \mathrm{NaCl}$ and $2.5 \mathrm{mM}$ DTT in a final volume of $200 \mu \mathrm{l}$ for $2 \mathrm{~h}$ at $37^{\circ} \mathrm{C}$. The fluorescence of the released 7-amino-4-methyl coumarin (amc) was measured using an excitation wave length of $365 \mathrm{~nm}$ and emission wave length of $450 \mathrm{~nm}$.

\section{Statistics}

Data are expressed as mean \pm S.E. Comparison between groups were done with a one-way analysis of variance followed by StudentNewman-Kuel's test. A $P$ value of less than 0.05 was considered to be significant.

\section{Acknowledgements}

This work was supported by grant HL 51005 (JPK), by a NIEHS Toxicology postdoctoral training grant ES 07247 (HKB), and by NIEHS Center Grant ES 07784. JPK is the Gustavus and Louise Pfeiffer Professor of Toxicology. Support from the MRC Toxicology Unit where HKB performed much of this work while on leave is also gratefully acknowledged.

\section{References}

1. Arends MJ and Wyllie AH (1991) Apoptosis: mechanisms and roles in pathology. Int. Rev. Exp. Pathol. 32: 223-254

2. Thompson CB (1995) Apoptosis in the pathogenesis and treatment of diseases. Science 267: $1456-1462$

3. Earnshaw WC (1995) Nuclear changes in apoptosis. Curr. Opin. Cell Biol. 7: $337-343$

4. Kumar S and Harvey NL (1995) Role of multiple cellular proteases in the execution of programmed cell death. FEBS Lett. 375: 169-173

5. Patel T, Gores GJ and Kaufmann SH (1996) The role of proteases during apoptosis. FASEB J. 10: 587-597

6. Cohen GM (1997) Caspases: the executioners of apoptosis. Biochem. J. 326: $1-16$

7. Thornberry NA and Molineaux SM (1995) Interleukin-1 beta converting enzyme: a novel cysteine protease required for IL-1 beta production and implicated in programmed cell death. Protein Sci. 4: 3-12

8. Henkart PA (1996) ICE family proteases: mediators of all apoptotic cell death? Immunity 4: 195-201

9. Lazebnik YA, Kaufmann SH, Desnoyers S, Poirier GG and Earnshaw WC (1994) Cleavage of poly(ADP-ribose)polymerase by a proteinase with properties like ICE. Nature 371: $346-347$

10. Kaufmann SH, Desnoyers S, Ottaviano Y, Davidson NE and Poirier GG (1993) Specific proteolytic cleavage of poly(ADP-ribose) polymerase: an early marker of chemotherapy-induced apoptosis. Cancer Res. 53: 3976-3985

11. Song Q, Lees-Miller SP, Kumar S, Zhang Z, Chan DW, Smith GCM, Jackson SP, Alnemri ES, Litwack G, Khanna KK and Lavin MF (1996) DNA-dependent protein kinase catalytic subunit: a target for an ICE-like protease in apoptosis. EMBO J. 15: $3238-3246$

12. Nicholson DW, Ali A, Thornberry NA, Vaillancourt JP, Ding CK, Gallant M, Gareau Y, Griffin PR, Labelle M, Lazebnik YA, Munday NA, Raju SM, Smulson ME, Yamin TT, Yu VL and Miller DK (1995) Identification and inhibition of the ICE/ CED-3 protease necessary for mammalian apoptosis. Nature 376: $37-43$ 
13. Fernandes-Alnemri T, Takahashi A, Armstrong R, Krebs J, Fritz L, Tomaselli KJ, Wang L, Yu Z, Croce CM, Salveson G, Earnshaw WC, Litweck G and Alnemri ES (1995) Mch3, a novel human apoptotic cysteine protease highly related to CPP32. Cancer Res. 55: 6045-6052

14. LiP, Allen H, Banerjee S, Franklin S, Herzog L, Johnston C, McDowell J, Paskind M, Rodman L, Salfeld J, Towne E, Tracey D, Wardwell S, Wai F-Y, Wong W, Kamen $R$ and Seshadri T (1995) Mice deficient in IL-1 beta-converting enzyme are defective in production of mature $\mathrm{IL}-1$ beta and resistant to endotoxic shock. Cell $80401-411$

15. Kuida K, Lippke JA, Ku G, Harding MW, Livingston DJ, Su MS and Flavell RA (1995) Altered cytokine export and apoptosis in mice deficient in interleukin-1 beta converting enzyme. Science 267: 2000-2003

16. Sandstrom PA, Mannie MD andButtke TM (1994) Inhibition of activation-induced death in T cell hybridomas by thiol antioxidants: oxidative stress as a mediator of apoptosis. J. Leukoc. Biol. 55: 221-226

17. Sarafian TA and Bredesen DE (1994) Is apoptosis mediated by reactive oxygen species? Free Rad. Res. 21: 1-8

18. Payne CM, Bernstein C and Bernstein H (1995) Apoptosis overview emphasizing the role of oxidative stress, DNA damage and signal-transducing pathways. Leuk. Lymphoma 19: 43-93

19. Slater AF, Nobel CS, Maellaro E, Bustamante J, Kimland M and Orrenius S (1995) Nitrone spin traps and a nitroxide antioxidant inhibit a common pathway of thymocyte apoptosis. Biochem. J. 306: 771-778

20. Satoh T, Sakai N, Enokido Y, Uchiyama Y and HatanakaH(1996) Survival factorinsensitive generation of reactive oxygen species induced by serum deprivation. Brain Res. 733: 9-14

21. Watson RW, Rotstein OD, Nathens AB, Dachiw AP and Marshall JC (1996) Thiol-mediated redox regulation of neutrophil apoptosis. Surgery 120: $150-157$

22. Bojes HK, Datta K, Xu J, Chin A, Simonian P, Nunez G and Kehrer JP (1997) Bcl$\mathrm{xL}$ overexpression attenuates glutathione depletion in FL5.12 cells following IL-3 withdrawal. Biochem. J. 325: 315-319

23. Beaver JP and Waring $P$ (1995) A decrease in intracellular glutathione concentration precedes the onset of apoptosis in murine thymocytes. Eur. J. Cell Biol. 68: $47-54$

24. van den Dobblesteen DJ, Nobel CS, Schlegel J, Cotgreave IA, Orrenius S and Slater AF (1996) Rapid and specific efflux of reduced glutathione during apoptosis induced by anti-Fas/APO-1 antibody. J. Biol. Chem. 271: 1542015427

25. Ghibelli L, Fanelli C, Rotilio G, Lafavia E, Coppola S, Colussi C, Civitareale P and Ciriolo MR (1998) Rescue of cells from apoptosis by inhibition of active GSH extrusion. FASEB J 12: 479-486

26. Zhu H, Fearnhead HO and Cohen GM (1995) An ICE-like protease is a common mediator of apoptosis induced by diverse stimuli in human monocytic THP.1 cells. FEBS Lett. 374: 303-308

27. MacFarlane M, Cane K, Sun X-M, Alnemri ES and Cohen GM (1997) Processing/ activation of at least four interleukin- $1 \beta$ converting enzyme-like proteases occurs during the execution phase of apoptosis in human monocytic tumor cells. J. Cell Biol. 137: $469-479$

28. Armstrong RC, Aja T, Xiang J, Gaur S, Krebs JF, Hoang K, Bai X, Korsmeyer SJ, Karanewsky DS, Fritz LC and Tomaselli KJ (1996) Fas-induced activation of the cell death-related protease CPP32 is inhibited by Bcl-2 and by ICE family protease inhibitors. J. Biol. Chem. 271: 16850-16855

29. Duke RC and Cohen JJ (1992) In: Current Protocols in Imunology; Colligan JE and Kruisbeak AM, eds. John Wiley and Sons: New York pp. 3.17.1-3.17.6

30. Deshmunk M, Vasilakos J, Deckwerth TL, Lampe PA, Shivers BD and Johnson Jr EM (1996) Genetic and metabolic status of NGF-deprived sympathetic neurons saved by an inhibitor of ICE family proteases. J. Cell Biol. 135: $1341-1354$

31. Zamzami N, Marchetti P, Castedo M, Zanin C, Vayssiere J-L, Petit PX and Kroemer G (1995) Reduction in mitochondrial potential constitutes an early irreversible step of programmed lymphocyte death in vivo. J. Exp. Med. 181: 1661 - 1672

32. Petit PX, Lecouer H, Zorn E, Dauguet C, Mignotte B and Gougeon ML (1995) Alterations in mitochondrial structure and function are early events of dexamethasone-induced thymocyte apoptosis. J. Cell Biol. 130: 157167

33. Kroemer G, Petit PX, Zamzami N, Vayssiere J-L and Mignotte B (1995) The biochemistry of programmed cell death. FASEB J 9: 1277-1287
34. Fernandes-Alnemri T, Litwack G and Alnemri ES (1994) CPP32, a novel human apoptotic protein with homology to Caenorhabditis elegans cell death protein Ced-3 and mammalian interleukin-1 beta-converting enzymes. J. Biol. Chem. 269: 30761-30764

35. Orth K, Chinnaiyan AM, Garg M, Froelich CJ and Dixit VM (1996) The CED-3/ ICE-like protease Mch2 is activated during apoptosis and cleaves the death substrate lamin A. J. Biol. Chem. 271: 16443-16446

36. Takahashi A, Alnemri ES, Lazebnik YA, Fernandes-Alnemri T, Litwack G, Moir RD, Golman RD, Poirier GG, Kaufman SH and Earnshaw WC (1996) Cleavage of lamin $\mathrm{A}$ by Mch $2 \alpha$ but not CPP32: multiple interleukin $1 \beta$-converting enzymerelated proteases with distinct substrate recognition properties are active in apoptosis. Proc. Natl. Acad. Sci. 93: 8395-8400

37. Ohta T, Kinoshita T, Naito M, Nozaki T, Masutani M, Tsuruo T and Miyajima A (1997) Requirement of the caspase-3/CPP32 protease cascade for apoptotic death following cytokine deprivation in hematopoietic cells. J. Biol. Chem. 272: $23111-23116$

38. Vasilakos JP, Lynch T, Ghayur T, Giegel DA, Santoro M and Shivers BD (1997) Caspase-3/CPP32-like activity is not sufficient to mediate apoptosis in an IL-2 dependent T cell line. Apoptosis 2: 289-303

39. Xiang J, Chao DT and Korsmeyer SJ (1996) BAX-induced cell death may not require interleukin-1 beta-converting enzyme-like proteases. Proc. Natl. Acad. Sci. 93: 14559-14563

40. McCarthy NJ, Whyte MKB, Gilbert CS and Evan GI (1997) Inhibition of Ced-3/ ICE-related proteases does not prevent cell death induced by oncogenes, DNA damage, or the Bcl-2 homologue Bak. J. Cell Biol. 136: 215-227

41. Miller TM, Moulder KL, Knudson CM, Creedon DJ, Deshmunk M, Korsmeyer SJ and Johnson Jr EM (1997) Bax deletion further orders the cell death pathway in cerebellar granule cells and suggests a caspase-independent pathway to cell death. J. Cell Biol. 139: 205-217

42. Liu X, Kim CN, Yang J, Jemmerson R and Wang X (1996) Induction of apoptotic program in cell-free extracts: requirement for dATP and cytochrome c. Cell 86: $147-157$

43. Benson RSP, Dive C and Watson AJM (1998) Comparative effects of Bcl-2 overexpression and ZVAD.FMK treatment on dexamethason and VP16-induced apoptosis in CEM cells. Cell Death Differ. 5: 432-439

44. Brunet CL, Gunby RH, Benson RSP, Hickman JA, Watson AJM and Brady G (1998) Commitment to cell death measured by loss of clonogenicity is separable from the appearance of apoptotic markers. Cell Death Differ. 5: 107-115

45. Hirsch T, Marchetti P, Susin SA, Dallaporta B, Zamzami N, Marzo I, Geuskens M and Kroemer G (1997) The apoptosis-necrosis paradox, Apoptogenic proteases activated after mitochondrial permeability transition determine the mode of cell death. Oncogene 15: 1573-1581

46. Vasilakos JP, Ghayur T, Carroll RT, Giegel DA, Saunders JM, Quintal L, Keane KM and Shivers BD (1995) IL-1 beta converting enzyme (ICE) is not required for apoptosis induced by lymphokine deprivation in an IL-2-dependent T cell line. J. Immunol. 155: 3433-3442

47. Muzio M, Chinnaiyan AM, KischkelFC, O'Rourke K, Shevchenko A, Ni J, Scaffidi C, Bertz JD, Zhang M, Getz R, Mann M, Krammer PH, Peter ME, Dixit VM (1996) FLICE, a novel FADD-homologous ICE/CED-3-like protease, is recruited to the CD95 (Fas/APO-1) death-inducing signaling complex. Cell 85: 817-827

48. Boldin MP, Goncharov TM, Goltsev YV and Wallach D (1996) Involvement of $\mathrm{MACH}$, a novel MORT/FADD-interacting protease, in Fas/APO-1 and TNF receptor-induced cell death. Cell 85: 803-815

49. Voehringer DW, McConkey DJ, McDonnell TJ, Brisbay S and Meyn RE (1998) $\mathrm{Bcl}-2$ expression causes redistribution of glutathione to the nucleus. Proc. Natl. Acad. Sci. USA 94: 2956-2960

50. Kane DJ, Sarafian TA, Anton R, Hahn H, Gralla EB, Valentine JS, Ord T and Bredesen DE (1993) Bcl-2 inhibition of neural death: decreased generation of reactive oxygen species. Science 262: $1274-1277$

51. Mirkovic N, Voehringer DW, Story MD, McConkey DJ, McDonnell TJ and Meyn $\mathrm{RE}$ (1997) Resistance to radiation-induced apoptosis in Bcl-2-expressing cells is reversed by depleting cellular thiols. Oncogene 15: 1461-1470

52. Sato N, Iwata S, Nakamura K, Hori T, Mori K and Yodoi J (1995) Thiol-mediated redox regulation of apoptosis. Possible roles of cellular thiols other than glutathione in T cell apoptosis. J. Immunol. 154: 3194-3203

53. Hampton MB and Orrenius S (1997) Dual regulation of caspase activity by hydrogen peroxide: implications for apoptosis. FEBS Lett. 414: $552-$ 556

54. Lee JC, Hapel AJ and Ihle JN (1982) Constitutive production of a unique lymphokine (IL-3) by WEHI-3 cell line. J Immunol 128: 2393-2398 
55. Koopman G, Reutelingsperger CP, Kuijten GA, Keehnen RM, Pals ST and van Oers MH (1994) Annexin V for flow cytometric detection of phosphatidylserine expression on B cells undergoing apoptosis. Blood 84: 1415-1420

56. Vermes I, Haanen C, Steffens-Nakken H and Reutelingsperger C (1995) A nove assay for apoptosis. Flow cytometric detection of phosphatidylserine expression on early apoptotic cells using fluorescein labelled Annexin V. J. Immunol. Methods 184: $39-51$
57. Martin J and White IN (1991) Fluorimetric determination of oxidised and reduced glutathione in cells and tissues by high-performance liquid chromatography following dervatization with dansyl chloride. J. Chromatogr. 568: 219-225

58. Mizushima N, Koike R, Kohsaka H, Kushi Y, Handa S, Yagita H and Miyasaka N (1996) Ceramide incudes apoptosis via CPP32 activation. FEBS Lett. 395:267271 